Imperial Encounters 



\section{Imperial Encounters}

RELIGION AND MODERNITY IN INDIA AND BRITAIN

Peter van der Veer

$\begin{array}{lllllllllllllllllllllllll}P & R & I & N & C & E & T & O & N & U & N & I & V & E & R & S & I & T & Y & P & R & E & S & S\end{array}$

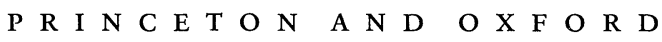


Copyright (c) 2001 by Princeton University Press Published by Princeton University Press, 41 William Street, Princeton, New Jersey 08540 In the United Kingdom: Princeton University Press, 3 Market Place, Woodstock, Oxfordshire OX20 1SY All Rights Reserved

ISBN 0-691-07477-1 (cloth) ISBN 0-691-07478-X (alk. paper)

This book has been composed in Sabon

The paper used in this publication meets the minimum requirements of ANSI/NISO Z39.48-1992 (R1997)

(Permanence of Paper) www.pup.princeton.edu

Printed in the United States of America $\begin{array}{llllllllll}10 & 9 & 8 & 7 & 6 & 5 & 4 & 3 & 2 & 1\end{array}$ 
FOR JACOBIEN, JAN ANNE, AND SJOERD 
